\title{
The effect of inulin on broiler chicken intestinal microflora, gut morphology, and performance
}

\author{
A. Nabizadeh ${ }^{1}$ \\ Islamic Azad University, Department of Animal Sciences \\ Bojnourd - Branch \\ South 17 Shahrivar Street, 94176-97796 Bojnourd, North Khorasan, Iran
}

(Received 28 December 2011; revised version 24 August 2012; accepted 15 November 2012)

\begin{abstract}
This study was conducted to evaluate the effectiveness of inulin on the intestinal microflora, gut morphology, and performance of broiler chickens. After sex identification, 168 male Ross 308 broilers were randomly allotted to 3 treatment groups with 4 replicates and fed for 42 days. Experimental treatments including $0 \%, 0.5 \%$, or $1 \%$ inulin were used. The experimental diets were formulated based on maize-soyabean meal. The results showed that livability and body weight gain were better for broilers fed diets supplemented with inulin, but livability did not vary significantly among groups and the control. Live body weight on $\mathrm{d} 42$ was significantly increased when the diets were supplemented with $1 \%$ inulin. Feed intake and feed conversion ratio were not affected in birds fed diets with supplements in comparison with the control group. Inulin inclusion had no effect on Bifidobacteria, Lactobacilli and E. coli counts in ileal contents, but significantly increased Bifidobacteria counts and decreased E. coli counts in caecal contents. With the exception of significantly increased villus height in the ileum, the morphological measurements of the duodenum, jejunum, and ileum showed no response to dietary levels of inulin as compared with the control diet. In conclusion, the results from the current study suggest that feeding inulin may have a beneficial effect on intestinal microflora and morphology, and on the performance of broiler chickens.
\end{abstract}

KEY WORDS: broiler chickens, inulin, intestinal microflora, gut morphology, performance

\section{INTRODUCTION}

Over the past few decades, antibiotics have been added to poultry and pig diets to maintain health and production efficiency (Rosen, 1995). There is increasing

\footnotetext{
${ }^{1}$ Corresponding author: e-mail: alinabizadehalinabizadeh@yahoo.com; nabizade@bojnourdiau.ac.ir
} 
concern, however, about the risk of developing cross-resistance and multipleantibiotic resistance in pathogenic bacteria (Verdonk and Shim, 2005). Because of this risk, antibiotics are being removed from poultry and pig diets around the world. This perspective has stimulated nutritionists and feed manufacturers to search for new, safer alternatives. Thus, in recent years, we have seen a growing interest in feed additives that may act as alternatives to antibiotics. These additives include mixtures of organic acids, prebiotics, probiotics, symbiotics, and feed enzymes. One possible alternative to antibiotics might be found in the use of certain prebiotics such as inulin (Rebolé et al., 2010). A prebiotic is a selectively fermented ingredient that allows specific changes in the composition or activity of the gastrointestinal microbiota and is not digested by the host's digestive enzymes (Gibson et al., 2004). The growth of endogenous microbial population groups such as Bifidobacteria and Lactobacilli is specifically stimulated and these bacteria species are perceived as beneficial to animal health, thus improving the host's microbial balance. Inulin, extracted from chicory (Cichorium intybus), contains molecules with a degree of polymerization of 3 to 60 , the mean being 10 (Crittenden, 1999). Inulin therefore contains both oligosaccharides and polysaccharides. Thanks to the $\beta(2 \rightarrow 1)$ glycosidic bond, it is resistant to hostderived digestive enzymes and is believed to enhance the growth of healthpromoting bacteria and to suppress the growth of potential pathogenic bacteria (Zentek et al., 2003). Xu et al. (2003) observed improvements in body weight gain (BWG) when $4 \mathrm{~g} / \mathrm{kg}$ of fructooligosaccharides (FOS) were added to the basal diet. Rebolé et al. (2010) reported that inulin at levels of 10 and $20 \mathrm{~g} / \mathrm{kg}$ in a wheat- and barley-based diet has a beneficial effect on the BWG of broilers. Park and Park (2011) reported that a concentration of 200 and 250 g/ton of microencapsulated inulin improved BWG and the feed conversion ratio. In contrast with these findings, Biggs et al. (2007) used inulin or FOS at concentrations of 4 and $8 \mathrm{~g} / \mathrm{kg}$, and Rehman et al. (2008) used inulin at $10 \mathrm{~g} / \mathrm{kg}$ of diet and observed no positive effect on broiler growth performance. Feeding a higher level $(0.8 \%)$ of inulin and short-chain fructooligosaccharides depressed the growth performance and digestibility of amino acids as well as metabolizable energy of birds (Biggs et al., 2007). Some positive changes in digestive enzymes, gut morphology, and immune system were noticed in birds given prebiotic-supplemented feed (Xu et al., 2003). No information exists regarding the effects of inulin on the histology of the small intestine, although a few reports are available showing that the villus height of the small intestine is increased in broilers supplemented with fermentable carbohydrates like fructooligosaccharides (Xu et al., 2003).

The optimal dose for prebiotics to exert growth-promoting effects is not easy to define. Compared with the application of prebiotics in human and pet food, the use of prebiotics in broiler chicken diets does not have a long history, and reports on their effects on the activity of the microflora of broilers are limited and the 
effects are variable (Yang et al., 2009). Therefore, the purpose of this study was to evaluate the effect of different dietary inulin levels on the intestinal microflora, gut morphology, and performance of broiler chickens.

\section{MATERIAL AND METHODS}

\section{Birds and housing}

A total of 168 male, one-day-old Ross 308 broiler chicks of an average $41.09 \mathrm{~g}$ body weight were obtained from a commercial hatchery and were randomly allocated to 3 treatments with 4 replicate pens of 14 birds each. Each pen had a surface area of 1.28 square meters. The research was conducted from 25 May 2011 to 6 July 2011 and was carried out on a private farm that belongs to Movahhed Gostaran Jovain Company (MGJC) in Iran. All chickens had ad libitum access to antibiotic-free feed and clean water under controlled ventilation throughout the experiment. During the first $3 \mathrm{~d}$, the chickens were provided with $24 \mathrm{~h}$ of light, after which lighting was decreased to $18 \mathrm{~h}$ by the end of the trial. Temperature was maintained at $32^{\circ} \mathrm{C}$ for the first $3 \mathrm{~d}$ and then gradually was reduced according to normal management practices until a temperature of $21^{\circ} \mathrm{C}$ was achieved on $\mathrm{d} 24$. To protect the birds against viral diseases, especially like Newcastle disease (ND) and Infectious Bursal Disease (IBD), all birds were also vaccinated as per schedule followed by MGJC. None of the diets contained coccidiostats, antibiotics, or growth promoters.

Diets

Three experimental diets including $0 \%, 0.5 \%$, or $1 \%$ of inulin were used. The inulin used in this study was a commercial product (Orafti ${ }^{\circledR}$ GR, BENEOOrafti B 3300, Tienen, Belgium), obtained from chicory roots, with a degree of polymerization (DP) of carbohydrates $\geq 10.92 \%$ inulin content, $10 \%$ sweetness, according to the manufacturer's data sheet. The diets were isocaloric and isonitrogenous based on the Ross Broiler Nutrition Specification (2007) recommendation and were offered in mash form. The composition of the experimental diets is shown in Table 1.

\section{Performance measurements}

Records for live body weight and feed consumption were obtained at the end of each period. Weight gain, feed intake, and feed conversion ratio (FCR) were calculated. Mortality was recorded as it occurred and was added to the total pen 
Table 1. Composition and nutrient concentration of diets ${ }^{1}, \mathrm{~g} / \mathrm{kg}$

\begin{tabular}{|c|c|c|c|c|c|c|c|c|c|}
\hline \multirow{2}{*}{ Indices } & \multicolumn{3}{|c|}{ Starter, \% inulin } & \multicolumn{3}{|c|}{ Grower, \% inulin } & \multicolumn{3}{|c|}{ Finisher, \% inulin } \\
\hline & 0 & 0.5 & 1 & 0 & 0.5 & 1 & 0 & 0.5 & 1 \\
\hline \multicolumn{10}{|l|}{ Ingredients } \\
\hline maize grain & 502.4 & 491.2 & 480.0 & 463.8 & 453.6 & 448.7 & 508.9 & 502.4 & 480.8 \\
\hline soyabean meal & 388.2 & 390.5 & 392.7 & 359.0 & 361.7 & 362.1 & 303.4 & 302.5 & 302.8 \\
\hline wheat grain & 10.0 & 10.0 & 10.0 & 67.3 & 65.8 & 64.7 & 79.7 & 81.2 & 93.1 \\
\hline soyabean oil & 51.6 & 55.6 & 59.6 & 70.0 & 74.0 & 74.5 & 70.0 & 70.9 & 75.4 \\
\hline limestone & 14.4 & 14.4 & 14.4 & 11.1 & 11.1 & 11.1 & 10.6 & 10.6 & 10.5 \\
\hline dicalcium phosphate & 17.7 & 17.7 & 17.7 & 16.3 & 16.3 & 16.3 & 15.3 & 15.3 & 15.3 \\
\hline $\mathrm{NaCl}$ & 4.0 & 4.0 & 4.0 & 4.0 & 4.0 & 4.0 & 4.0 & 4.0 & 4.0 \\
\hline vitamin premix ${ }^{2}$ & 2.5 & 2.5 & 2.5 & 2.5 & 2.5 & 2.5 & 2.5 & 2.5 & 2.5 \\
\hline mineral premix ${ }^{3}$ & 2.5 & 2.5 & 2.5 & 2.5 & 2.5 & 2.5 & 2.5 & 2.5 & 2.5 \\
\hline DL-methionine & 3.3 & 3.3 & 3.3 & 1.8 & 1.8 & 1.9 & 1.5 & 1.5 & 1.5 \\
\hline L-lysine $\mathrm{HCl}$ & 3.4 & 3.3 & 3.3 & 1.7 & 1.7 & 1.7 & 1.6 & 1.6 & 1.6 \\
\hline inulin & 0.0 & 5.0 & 10.0 & 0.0 & 5.0 & 10.0 & 0.0 & 5.0 & 10.0 \\
\hline \multicolumn{10}{|l|}{ Calculated analysis } \\
\hline ME, kcal/ kg & 3025 & 3025 & 3025 & 3150 & 3150 & 3150 & 3200 & 3200 & 3200 \\
\hline protein & 220 & 220 & 220 & 210 & 210 & 210 & 190 & 190 & 190 \\
\hline $\mathrm{Ca}$ & 10.5 & 10.5 & 10.5 & 9.0 & 9.0 & 9.0 & 8.5 & 8.5 & 8.5 \\
\hline available $\mathrm{P}$ & 5.0 & 5.0 & 5.0 & 4.5 & 4.5 & 4.5 & 4.2 & 4.2 & 4.2 \\
\hline $\mathrm{Na}$ & 1.7 & 1.7 & 1.7 & 1.7 & 1.7 & 1.7 & 1.7 & 1.7 & 1.7 \\
\hline lysine & 14.3 & 14.3 & 14.3 & 12.4 & 12.4 & 12.4 & 10.9 & 10.9 & 10.9 \\
\hline Met + Cys & 10.2 & 10.2 & 10.2 & 8.5 & 8.5 & 8.5 & 7.7 & 7.7 & 7.7 \\
\hline
\end{tabular}

live body weight for the calculation of FCR at each period. The European Production Efficiency Factor (EPEF) was calculated according to the following equation:

$$
\text { EPEF } \times \frac{\text { livability } \% \times \text { liveweight }(\mathrm{kg})}{\text { age (day) } \mathrm{x} \text { FCR }} \times 100
$$

\section{Samples collection and measurements}

At the end of the experiment, two chickens, close to the average pen weight from each replicate, were randomly selected, given anaesthetics, and sacrificed. After laparotomy, segments of the digestive tract (small intestine and caeca) were removed. The small intestine was divided into three segments: duodenum (from the gizzard to the pancreo-biliary ducts), jejunum (from the pancreo-biliary ducts to Meckel's diverticulum), and ileum (from Meckel's diverticulum to the ileocaecal junction). As soon as possible after killing, the $\mathrm{pH}$ of ileal and caecal (one side randomly) digesta were measured on fresh samples $(1 \mathrm{~g})$ diluted with $10 \mathrm{ml}$ of deionized water and using an electrode and a pH meter (Labtron, PHT-110, Iran). 
Their ileal and caecal (mixture of both caecum) contents were mixed and placed in a micro tube and immediately stored at $-70^{\circ} \mathrm{C}$ until used for microbial analysis. Segments about $1 \mathrm{~cm}$ in length from the midpoint of the duodenal, jejunal and ileal samples were cut. First, they were washed with sterilized physiological saline solution to remove any adherent intestinal content, then they were fixed in $10 \%$ buffered formalin for histological study.

Microbial populations were determined by serial dilution of ileal and caecal samples in anaerobic diluents before inoculation onto Petri dishes of sterile agar as described by Bryant and Burkey (1953). Lactobacilli were grown on Rogosa SL agar, Bifidobacteria were grown on BIM-25 agar (Munoa and Pares, 1988), and E. coli was grown on EMB agar. Plates for Lactobacillus were incubated anaerobically for $24 \mathrm{~h}$ at $37^{\circ} \mathrm{C}$. Plates for Bifidobacteria were incubated anaerobically for $48 \mathrm{~h}$ at $37^{\circ} \mathrm{C}$, those for $E$. coli were incubated aerobically for 24 $\mathrm{h}$ at $37^{\circ} \mathrm{C}$. The plates were counted after incubation. The number of colonies was then counted to determine the colony forming units (CFU) per gram of fresh ileal and caecal contents, which were then expressed in common logarithms.

Intestinal samples were transferred from formalin after dehydration in an ethanol series, cleaned in xylene and embedded in paraffin. Intestinal samples $5 \mu \mathrm{m}$ thick were obtained using a microtome (Leica RM 2145), placed on glass slides, prepared and processed for staining with haematoxylin and eosin ( $\mathrm{H}$ and E). Micrographs were taken with an Olympus microscope, BX41 (Olympus, Tokyo, Japan). Morphometric measurements were performed on 9 villi chosen from each sample; magnification was 5 for villi and 10 for crypts. The included morphometric indices were villus height from the tip of the villus to the crypt and crypt depth from the base of the villi to the submucosa.

\section{Statistical analysis}

Data were analysed in a completely randomized design by one-way analysis of variance (ANOVA) in non-orthogonal designs by using the MSTATC (Freed, 1997) software package. Means were compared by Duncan's multiple-range test and differences were considered significant at when the P-values were less than 0.05 .

\section{RESULTS}

Table 2 shows body weight gain, feed intake, feed conversion ratio, the European Production Efficiency Factor (EPEF), livability percent, initial body weight, and final body weight in broilers fed diets with different levels of inulin. 
Table 2. Body weight gain, feed intake, feed conversion ratio, EPEF, and livability of broiler chickens

\begin{tabular}{|c|c|c|c|c|}
\hline \multirow{2}{*}{ Indices } & \multicolumn{3}{|c|}{ Dietary treatments inulin, \% } & \multirow{2}{*}{ SEM } \\
\hline & 0 & 0.5 & 1 & \\
\hline \multicolumn{5}{|l|}{ Body weight gain, g/chicken/day } \\
\hline $0-10$ day & 22.6 & 22.7 & 22.1 & 0.308 \\
\hline 11-24 day & 45.2 & 44.0 & 44.6 & 0.505 \\
\hline $25-42$ day & $69.3^{\mathrm{b}}$ & $70.2^{\mathrm{b}}$ & $74.8^{\mathrm{a}}$ & 0.550 \\
\hline $0-42$ day & 50.1 & 50.2 & 52.2 & 0.367 \\
\hline \multicolumn{5}{|l|}{ Feed intake, g/chicken/day } \\
\hline 0-10 day & 23.2 & 23.2 & 22.7 & 0.415 \\
\hline $11-24$ day & 89.6 & 88.3 & 87.2 & 0.559 \\
\hline $25-42$ day & 137 & 135 & 134 & 0.776 \\
\hline 0-42 day & 89.6 & 88.3 & 87.2 & 0.559 \\
\hline \multicolumn{5}{|l|}{ Feed conversion ratio, g/g } \\
\hline 0-10 day & 0.97 & 1.06 & 1.03 & 0.071 \\
\hline $11-24$ day & 1.71 & 1.67 & 1.66 & 0.087 \\
\hline $25-42$ day & 1.98 & 1.93 & 1.79 & 0.100 \\
\hline 0-42 day & 1.79 & 1.76 & 1.67 & 0.071 \\
\hline EPEF & $270^{c}$ & $280^{\mathrm{b}}$ & $313^{\mathrm{a}}$ & 1.346 \\
\hline Livability \% & 96.4 & 98.2 & 100 & 0.627 \\
\hline Final body weight, g/chicken & $2105^{\mathrm{b}}$ & $2107^{\mathrm{b}}$ & $2194^{\mathrm{a}}$ & 2.072 \\
\hline
\end{tabular}

The body weight gain was significantly increased when the diets were supplemented with $1 \%$ inulin. The dietary inulin treatments had no effect on feed intake or FCR in comparison with the control group. The EPEF was significantly increased by increasing inulin levels. Increasing the inulin levels had no significant effect on the livability percent. The results for $\mathrm{pH}$ and microflora counts in ileal and caecal digesta are presented in Table 3. Inulin supplementation had no significant effect on the $\mathrm{pH}$ of digesta and microflora counts in the ileal contents but significantly increased Bifidobacteria counts and decreased E. coli counts in caecal contents. The $\mathrm{pH}$ of caecal contents significantly decreased when the diets supplemented with $1 \%$ inulin. The villus height, crypt depth, and villus height-to-crypt depth ratio in the duodenum, jejunum, and ileum of broilers fed inulin-supplemented diets are shown in Table 4. In comparison with the control diet, the inclusion of inulin had no effect on villus height, crypt depth, or the villus height-to-crypt depth ratio of the duodenum and jejunum on $\mathrm{d} 42$. Inulin supplementation of diets did not affect crypt depth and villus height-to-crypt depth ratio of the ileum, but significantly increased villus height in the ileum. 
Table 3. $\mathrm{pH}$ and microflora counts in ileal and caecal digesta of broiler fed the experimental diets for 42 days, $\log 10 \mathrm{cfu} \mathrm{g}^{-1}$ content

\begin{tabular}{|c|c|c|c|c|}
\hline \multirow{2}{*}{ Indices } & \multicolumn{3}{|c|}{ Dietary treatments inulin, \% } & \multirow{2}{*}{ SEM } \\
\hline & 0 & 0.5 & 1 & \\
\hline \multicolumn{5}{|c|}{ pH of digesta } \\
\hline ileum & 5.84 & 5.81 & 5.72 & 0.050 \\
\hline caecum & $6.48^{\mathrm{a}}$ & $6.23^{\mathrm{ab}}$ & $5.73^{\mathrm{b}}$ & 0.100 \\
\hline \multicolumn{5}{|c|}{ Lactobacillus } \\
\hline ileum & 7.29 & 7.42 & 7.54 & 0.071 \\
\hline caecum & 8.18 & 8.48 & 8.83 & 0.224 \\
\hline \multicolumn{5}{|c|}{ Bifidobacteria } \\
\hline ileum & 6.22 & 7.01 & 6.77 & 0.200 \\
\hline caecum & $7.91^{\mathrm{b}}$ & $8.30^{\mathrm{ab}}$ & $8.74^{\mathrm{a}}$ & 0.100 \\
\hline \multicolumn{5}{|c|}{ Escherichia coli } \\
\hline ileum & 7.06 & 6.64 & 6.18 & 0.245 \\
\hline caecum & $8.76^{\mathrm{a}}$ & $7.54^{\mathrm{b}}$ & $6.29^{c}$ & 0.071 \\
\hline
\end{tabular}

means in the same row with different letters are significantly different at $\mathrm{P} \leq 0.05$

SEM - standard error of mean

Table 4. Effecs of dietary treatments on villus height, crypt depth, and villus height to crypt depth ratio in the duodenum, jejunum and ileum of broiler chickens at $42 \mathrm{~d}$ of age

\begin{tabular}{|c|c|c|c|c|}
\hline \multirow{2}{*}{ Indices } & \multicolumn{3}{|c|}{ Dietary treatments inulin, \% } & \multirow{2}{*}{ SEM } \\
\hline & 0 & 0.5 & 1 & \\
\hline \multicolumn{5}{|l|}{ Duodenum } \\
\hline villus height, $\mu \mathrm{m}$ & 703 & 700 & 697 & 1.353 \\
\hline crypt depth, $\mu \mathrm{m}$ & 133 & 137 & 138 & 0.896 \\
\hline crypt depth, $\mu \mathrm{m}$ & 133 & 137 & 138 & 0.896 \\
\hline \multicolumn{5}{|l|}{ Jejunum } \\
\hline villus height, $\mu \mathrm{m}$ & 668 & 671 & 671 & 1.292 \\
\hline crypt depth $\mu \mathrm{m}$ & 128 & 131 & 130 & 0.914 \\
\hline villus height:crypt depth ratio & 5.23 & 5.12 & 5.16 & 0.173 \\
\hline \multicolumn{5}{|l|}{ Ileum } \\
\hline villus height, $\mu \mathrm{m}$ & $524^{\mathrm{b}}$ & $549^{\mathrm{a}}$ & $553^{\mathrm{a}}$ & 1.783 \\
\hline crypt depth $(\mu \mathrm{m})$ & 111 & 114 & 116 & 1.068 \\
\hline villus height to crypt depth ratio & 4.71 & 4.83 & 4.79 & 0.235 \\
\hline
\end{tabular}

means in the same row with different letters are significantly different at $\mathrm{P} \leq 0.05$

SEM - standard error of mean

\section{DISCUSSION}

The available information that concerns the effect of inulin on broiler performance shows conflicting results. Ortiz et al. (2009) and Alzueta et al. (2010) found that dietary inclusion of inulin up to $20 \mathrm{~g} / \mathrm{kg}$ did not significantly affect $(\mathrm{P}>0.05)$ the BWG, feed intake, or FCR of broiler chickens. Similarly, Biggs et al. (2007) showed that feeding 4 or $8 \mathrm{~g} / \mathrm{kg}$ inulin had no effect on the growth performance of young chickens. Rehman et al. (2008) also reported that inulin did not affect final body weight compared with control birds. In contrast with 
these findings, the work of Rebolé et al. (2010) showed that inclusion of inulin in the control diet had a positive effect on the BWG of birds. This variability in the effectiveness of inulin may be due to the effect of different factors: inulin source, inclusion level of supplements, type of diet, animal characteristics, degree of hygiene, husbandry conditions, and environmental stress (Verdonk and Shim, 2005). The current study showed that BWG was significantly increased when the diets were supplemented with $1 \%$ inulin. Dietary inulin significantly improved the apparent ileal digestibility of crude protein and crude fat. Also, a significant effect of inulin has been shown on the digestibility of most amino acids and major fatty acids, i.e., oleic and linoleic acids (Alzueta et al., 2010). This can mean better body weight gain when the diets are supplemented with $1 \%$ inulin.

Inulin supplementation caused no significant differences in the $\mathrm{pH}$ of ileal digesta, but the $\mathrm{pH}$ of the caecal contents significantly decreased when the diets were supplemented with $1 \%$ inulin. Lowering the caecal content $\mathrm{pH}$ by inulin has also been shown in other studies (Józefiak et al., 2008). Because FOS is not hydrolysed by enzymes in the small intestine of monogastrics, it reaches the colon intact. FOS is fully metabolized by colonic microflora. The end products of carbohydrate fermentation are gases, lactate, and SCFA such as acetate, propionate, and butyrate. The caecum in broiler chickens is the main fermentative chamber and, in comparison with other gastrointestinal tract segments, contains the largest number of bacteria. Thus, the ability of microbiota to ferment carbohydrates there is very high (Józefiak et al., 2004). The present study showed that inulin supplementation caused no significant differences in the microflora counts in ileal contents but significantly increased Bifidobacteria counts and decreased E. coli counts in caecal contents. These results are in agreement with the findings of Rebolé et al. (2010), who found that inulin significantly increased Bifidobacteria in the caeca of broilers. Park and Park (2011) also reported that microencapsulated inulin significantly increased Bifidobacteria, and decreased E. coli counts. Because of the $\beta(2 \rightarrow 1)$ glycosidic bond, inulin is resistant to host-derived digestive enzymes and is believed to enhance the growth of health-promoting bacteria and to suppress the growth of potential pathogenic bacteria (Zentek et al., 2003). Many Lactobacilli and bifidobacterial species are able to excrete natural antibiotics, which can have a broad spectrum of activity (e.g., lactocins, helveticins, curvacins, nisin, or bifidocin). For the Bifidobacteria, some species are able to exert antimicrobial effects on various Gram-positive and Gram-negative intestinal pathogens including Salmonellae, Campylobacters, and E. coli (Gibson and Wang, 1994). In the ileum, because of limiting the amount of substrates available to the beneficial microflora, dietary treatments had no significant effect on microflora counts.

The results of the current study show that the inclusion of inulin had no effect on villus height, crypt depth, and the villus height-to-crypt depth ratio in 
the duodenum and jejunum of broiler chickens on d 42. Inulin supplementation significantly increased ileal villus height in broiler chickens at $42 \mathrm{~d}$ of age. $\mathrm{Xu}$ et al. (2003) showed that feeding FOS (0.4\%) increased the ileal villus height, crypt depth, and villus height-to-crypt depth in broilers. Inulin-type fructans are fermented by gut bacteria to yield SCFA, mainly acetate, propionate, and butyrate, which has important physiological functions. In the digestive tract, butyrate can act directly (upper gastrointestinal tract or hindgut) or indirectly (small intestine) on tissue development and repair. Direct trophic effects have been demonstrated chiefly in cell proliferation studies, which demonstrated faster renewal of necrotic areas. The indirect actions of butyrate are believed to involve the hormono-neuroimmuno system. Butyrate has also been implicated in down-regulation of bacteria virulence, both by direct effects on virulence gene expression and by acting on cell proliferation of the host cells (Guilloteau et al., 2010).

\section{CONCLUSIONS}

The results of the present study showed that body weight and European Production Efficiency Factor significantly increased and feed conversion ratio slightly improved when the diet was supplemented with $1 \%$ inulin. Dietary inulin supplementation significantly decreased $E$. coli counts in caecal contents. It may be an alternative to antibiotics to manage gut health and improve the performance of broiler chickens.

\section{REFERENCES}

Alzueta C., Rodriguez M.L., Ortiz L.T., Rebole A., Trevino J., 2010. Effects of inulin on growth performance, nutrient digestibility and metabolisable energy in broiler chickens. Brit. Poultry Sci. 51, 393-398

Biggs P., Parsons C.M., Fahey G.C., 2007. Effects of Several oligosaccharides on growth performance, nutrient digestibilities, and caecal microbial populations in young chicks. Poultry Sci. 86, 2327-2336

Bryant M.P., Burkey L.A., 1953. Cultural methods and some characteristics of some of the more numerouse groups of bacteria in the bovine rumen. J. Dairy Sci. 36, 205-217

Crittenden G.R., 1999. Prebiotics. In: G.W. Tannock (Editor). Probiotics; A Critical Review. Horizon Scientific Press. Norwich (New Zealand), pp. 141-156

Freed R.D., 1997. MSTAT-C with MGRAPH. Version 2.00. East Lansing, Michigan State University. MI (USA)

Gibson G.R., Probert H.M., Van Loo J., Rastall R.A., Roberfroid M.B., 2004. Dietary modulation of the human colonic microbiota: Updating the concept of prebiotics. Nutr. Res. Rev. 17, 259-275

Gibson G.R., Wang X., 1994. Bifidognic properties of different type of fructo-oligosaccharides. Food Microbiol. 11, 491-498 
Guilloteau P., Martin L., Eeckhaut V., Ducatelle R., Zabielski R., Van Immerseel F., 2010. From the gut to the peripheral tissues: the multiple effects of butyrate. Nutr. Res. Rev. 23, 366-384

Józefiak D., Kaczmarek S., Rutkowski A., 2008. A note on the effects of selected prebiotics on the performance and ileal microbiota of broiler chickens. J. Anim. Feed Sci. 17, 392-397

Józefiak D., Rutkowski A., Martin S.A., 2004. Carbohydrate fermentation in the avian ceca - A review. Anim. Feed Sci. Tech. 113, 1-15

Munoa F.J., Pares R., 1988. Selective medium for isolation and enumeration of Bifidobacterium spp. Appl. Environ. Microbiol. 54, 1715-1718

Ortiz L.T., Oodriguez M.L., Alzueta C., Rebole A., Trevino J., 2009. Effect of inulin on growth performance, intestinal tract sizes, mineral retention and tibial bone mineralization in broiler chickens. Brit. Poultry Sci. 50, 325-332

Park S.O., Park B.S., 2011. Effect of dietary microencapsulated-inulin on carcass characteristics and growth performance in broiler chickens. J. Anim. Vet. Adv. 10, 1342-1349

Rebolé A., Ortiz L.T., Rodríguez M.L., Alzueta C., Treviño J., Velasco S., 2010. Effects of inulin and enzyme complex, individually or in combination, on growth performance, intestinal microflora, cecal fermentation characteristics, and jejunal histomorphology in broiler chickens fed a wheatand barley-based diet. Poultry Sci. 89, 276-278

Rehman H., Hellweg P., Taras D., Zentek J., 2008. Effects of dietary inulin on the intestinal short chain fatty acids and microbial ecology in broiler chickens as revealed by denaturing gradient gel electrophoresis. Poultry Sci. 87, 783-789

Rosen G.D., 1995. Antibacterials in poultry and pig nutrition. In: R.J. Wallace, A. Chessn (Editors). Biotechnology in Animal Feeds and Feeding Press, pp. 143-172

Verdonk J.M.A.J., Shim S.B., 2005. Application of inulin-type fructans in animal feed and pet food. Brit. J. Nutr. 93, S125-S138

Xu Z.R., Hu C.H., Xia M.S., Zhan X.A., Wang M.D., 2003. Effects of dietary fructooligosaccharides on digestive e enzyme activities, intestinal microflora and morphology of male broilers. Poultry Sci. 82, 1030-1036

Yang Y., Iji P.A., Choct M., 2009. Dietary modulation of gut microflora in broiler chickens: a review of the role of six kinds of alternatives to in-feed antibiotics. World Poultry. Sci. J. 65, 97-114

Zentek J., Marquart B., Pietrzak T., Ballevre O., Rochat F., 2003. Dietary effects on bifidobacteria and Clostridium perfringens in the canine intestinal tract. J. Anim. Physiol. Anim. Nutr. 87, 397-407 